\title{
Interaction of short-fragmented DNA with dipalmitoylphosphatidylcholine bilayers in presence of zinc
}

\author{
Daniela Uhríková ${ }^{1}$, Petra Pullmannová ${ }^{1}$, Margarida Bastos ${ }^{2}$, Sérgio S. Funari ${ }^{3}$ and José Teixeira ${ }^{4}$ \\ ${ }^{1}$ Department of Physical Chemistry of Drugs, Faculty of Pharmacy, Comenius University, Odbojárov 10, 83232 Bratislava, \\ Slovakia \\ ${ }^{2}$ CIQ(UP), Department of Chemistry, Faculty of Sciences, University of Porto, R. Campo Alegre 687, P-4169-007 Porto, \\ Portugal \\ ${ }^{3}$ HASYLAB at DESY, Notkestr. 63, D-22603 Hamburg, Germany \\ ${ }^{4}$ Laboratoire Léon Brillouin (CEA-CNRS), CEA Saclay, 91191 Gif-sur-Yvette Cedex, France
}

\begin{abstract}
The structure and temperature behaviour of the DNA+dipalmitoylphosphatidylcholine (DPPC) bilayer as a function of $\mathrm{ZnCl}_{2}$ concentration were examined using differential scanning calorimetry (DSC), small-angle neutron scattering (SANS) and small-angle X-ray diffraction (SAXD). Experiments revealed the coexistence of two lamellar phases in the mixture: the $L_{P C}$ phase, formed due to $\mathrm{Zn}^{2+}$ binding to the DPPC bilayers, and the condensed lamellar phase $L_{D N A+P C}$ with DNA strands packed between the DPPC bilayers. With increasing concentration of zinc, the temperature of the gel - liquid-crystal phase transition of DPPC increases in both phases, and the volume fraction of $L_{D N A+P C}$ phase decreases. In the gel state (at $20^{\circ} \mathrm{C}$ ), the repeat distance of $L_{D N A+P C}$ phase is constant, $d_{D N A+P C} \sim 8.3 \mathrm{~nm}$, up to $20 \mathrm{mmol} / \mathrm{l}$ of $\mathrm{ZnCl}_{2}$, and increases for higher concentrations of the salt. The periodicity of the $L_{P C}$ lamellar phase decreases substantially with the increasing concentration of the salt in the mixture. In the liquid-crystalline state, concentrations above $20 \mathrm{mmol} / 1 \mathrm{ZnCl}_{2}$ promote the dissolution of the $L_{D N A+P C}$ phase into DPPC $+\mathrm{Zn}^{2+}$ unilamellar vesicles and DNA is neutralized by $\mathrm{Zn}^{2+}$ ions. The screening of $\mathrm{Zn}^{2+}$ charge and the formation of a diffuse double layer due to increasing ionic strength of solution are responsible for the observed changes.
\end{abstract}

Key words: DPPC - DNA - Zinc - DSC - Small-angle scattering

\section{Introduction}

Among the first-row transition metals, zinc is second only to iron in terms of abundance and importance in biological systems. Zinc plays a fundamental role in several critical cellular functions such as protein metabolism, gene expression, structural and functional integrity of biomembranes, and in metabolic processes (Christianson 1991). In plants, zinc deficiency causes a rapid inhibition of their growth and development, and thus of final yield (Cakmak 2000). Compared with other micronutrients, zinc exists in biological systems in high concentrations, particularly in biomembranes. Ac-

Correspondence to: Daniela Uhríková, Department of Physical Chemistry of Drugs, Faculty of Pharmacy, Comenius University, Odbojárov 10, 83232 Bratislava, Slovakia

E-mail: daniela.uhrikova@fpharm.uniba.sk cording to Williams (1988), concentration of zinc in animal systems range from $<10^{-9} \mathrm{~mol} / \mathrm{l}$ in cytoplasm to $>10^{-3} \mathrm{~mol} / \mathrm{l}$ in some membrane vesicles. There are many binding sites for zinc within the membranes, particularly at the internal sites. Most of the critical functions of zinc in cells are related to its ability to form tetrahedral coordination bonds in different vital cell constituents.

Like all metal cations, zinc interacts electrostatically with anionic groups. In contrast to other divalent metal cations with similar ionic radius such as $\mathrm{Mg}^{2+}$, zinc ions possess a higher affinity to electronegative groups (Gresh and Šponer 1999). $\mathrm{Zn}^{2+}$ obviously binds more tightly. It forms a stable complex with the zwitterionic phospholipid headgroup. The changes in its conformation, hydration and the effect on gel liquid-crystal phase temperature of 1-palmitoyl-2-oleoyl-snglycero-3-phosphocholine (POPC) were studied by Binder et al. (2001). Dehydration of phospholipid headgroups due 
to complexation with zinc cations was suggested to increase fusogenic potency of lipid membranes. Binder at al. (2000) examined changes in secondary structure of histidine-rich fusogenic peptide with POPC due to zinc complexation. Zinc cations are among the strong inducers of DNA conformational changes. They influence denaturation and renaturation of DNA by stabilizing its double helix structure (Eichhorn and Shin 1968). Some three-dimensional DNA architectures can be stabilized by the presence of these cations. However, zinc can also often bind to nucleobases, mainly to the N7 position of purines or other nitrogenous sites that can destabilize DNA and cause local denaturation of the double helix (Šponer et al. 1998; Gresh and Šponer 1999).

More than three decades ago Budker at al. (1978) reported the ability of divalent metal cations to mediate the interaction between DNA and phosphatidylcholine vesicles. Earlier microcalorimetric and ESR studies performed in our laboratory indicated the formation of a new phase due to DNA interaction with dipalmitoylphosphatidylcholine (DPPC) vesicles in presence of $\mathrm{Mg}^{2+}$ (Vojčíková and Balgavý 1988; Vojčíková et al. 1989). Electron freeze fracture micrographs of DNA-phosphatidylcholines-Ca ${ }^{2+}$ mixture suggested structures with long-range organization (Tarahovsky et al. 1996, 1998; Khusainova et al. 1999). Small-angle X-ray diffractograms show two possible structural organizations of DPPC + DNA + divalent cation aggregates: we identified a condensed lamellar phase with DNA strands packed regularly between DPPC bilayers in the aggregate with $\mathrm{Mg}^{2+}$, with a lipid bilayer repeat distance $d \sim 8.0-7.6 \mathrm{~nm}$ and interhelical DNA-DNA distance $d_{D N A} \sim 6.4-6.0 \mathrm{~nm}$ in the temperature range $20-60^{\circ} \mathrm{C}$ (Uhríková et al. 2001). The coexistence of two lamellar phases was reported in aggregates $\mathrm{DNA}+\mathrm{DPPC}+$ divalent cations $\left(\mathrm{Ca}^{2+}, \mathrm{Mg}^{2+}, \mathrm{Mn}^{2+}\right)$ : the phase with DNA strands intercalated in the water layer between lipid bilayers (with a repeat distance $d \sim 7.8 \mathrm{~nm}$ ) and another with a repeat distance $d \sim 6.3 \mathrm{~nm}$ was interpreted as a phase formed by lipid bilayers only (Francescangeli et al. 2003; McManus et al. 2003; Uhríková et al. 2005a). The aggregates formed due to the interaction between DNA and dioleoylphosphatidylethanolamine in presence of $\mathrm{Mg}^{2+}$, $\mathrm{Ca}^{2+}, \mathrm{Fe}^{2+}, \mathrm{Mn}^{2+}$ and $\mathrm{Co}^{2+}$ show a condensed columnar inverted hexagonal phase $\mathrm{H}_{\mathrm{II}}{ }^{\mathrm{c}}$, where DNA strands are located in tubules formed by inverted micelles, packed with hexagonal symmetry (Francescangeli et al. 2004; Uhríková et al. 2005b). These experimental results indicate the ability of divalent cations to compact DNA into structures similar to those observed for DNA + lipid + cationic amphiphiles aggregates (Radler et al. 1997; Koltover et al. 1998). Potentially, these aggregates are gene delivery vehicles (Kovalenko et al. 1996; Sato et al. 2005).

The aim of the present work is to study the phase behaviour of the DNA + DPPC mixture as a function of zinc concentration and temperature. As documented above, zinc plays an important role in many biological processes. It is evident that an adequate supply of $\mathrm{Zn}^{2+}$ is critically important for cellular functions. However, zinc as well as others heavy metals, is toxic whenever excessive amounts are ingested. The toxicity of metals results from the formation of complexes with organic compounds. The knowledge of the structure and phase behaviour of the formed aggregates can contribute to the understanding of their toxicity.

Differential scanning calorimetry (DSC) was used to determine the effect of zinc on the temperature of DPPC gel - liquid-crystal phase transition in DNA + DPPC $+\mathrm{Zn}^{2+}$ mixture. Small-angle X-ray diffraction (SAXD) experiments were performed to examine the structural organization of the mixture in the gel and liquid-crystalline phase. The obtained experimental data revealed the need of small-angle neutron scattering (SANS) to fully understand structural changes in the mixture.

\section{Materials and Methods}

\section{Materials}

Short fragmented salmon sperm DNA (500-1000 bp; Applichem, Germany) was dissolved in $5 \mathrm{mmol} / \mathrm{l}$ (or 100 $\mathrm{mmol} / \mathrm{l}) \mathrm{NaCl}, \mathrm{pH} \sim 7$. The precise value of concentration was determined by measuring the absorbance $A_{\lambda}$ at $\lambda=260$ $\mathrm{nm}$. The purity of DNA was checked by measuring $A_{\lambda}$ at 260 and $280 \mathrm{~nm}$, and we have obtained $A_{260} / A_{280}>1.7$.

DPPC was purchased from Avanti Polar Lipids (USA). Solutions of $\mathrm{ZnCl}_{2}$ (Merck, Germany) were prepared in $5 \mathrm{mmol} / \mathrm{l}$ (or $100 \mathrm{mmo} / \mathrm{l}$ ) $\mathrm{NaCl}, \mathrm{pH} \sim 7$. Either redistilled water or $\mathrm{D}_{2} \mathrm{O}$ (99.9\%; Merck, Germany) were used for the preparation of solutions. Samples were prepared by hydration of a thin lipid film ( $5 \mathrm{mg}$ of lipid (10 mg for SANS experiments) per sample) with a solution of DNA and cations to obtain the required ratio DPPC: DNA $=3: 1 \mathrm{~mol} / \mathrm{base}$ and ions concentration.

DPPC + DNA samples at different ionic strength were prepared by hydration of the lipid film with $20 \mathrm{mmol} / 1 \mathrm{ZnCl}_{2}$. Highly concentrated $\mathrm{NaCl}$ solution was used for modulation of ionic strength in individual samples.

Multilamellar vesicles prepared from fully hydrated pure DPPC were used as reference sample. Unilamellar DPPC vesicles were prepared by extrusion of multilamellar vesicles at $\sim 50^{\circ} \mathrm{C}$, using polycarbonate filter with pores of $50 \mathrm{~nm}$ diameter according to MacDonald et al. (2001) and filled into $2 \mathrm{~mm}$ thick quartz cells (Hellma, Germany) for SANS.

The unilamellar DPPC vesicles in $\mathrm{ZnCl}_{2}$ were prepared by hydration of dry lipid with the $\mathrm{ZnCl}_{2}$ solution (in $5 \mathrm{mmol} / \mathrm{l}$ $\mathrm{NaCl}, \mathrm{pH} \sim 7$ ). The concentration of $\mathrm{ZnCl}_{2}$ was changed within the range $0-40 \mathrm{mmol} / \mathrm{l}$. The dispersions were homog- 
enized as described in Uhríková et al. (2008). For turbidity measurements, the samples were diluted to $0.3 \mathrm{mg} / \mathrm{ml} \mathrm{DPPC}$ concentration.

\section{Methods}

Differential scanning calorimetric experiments were performed on a MicroDSC III calorimeter (Setaram, France) using twin removable cells $(1 \mathrm{ml})$ and performing temperature scans between $20-60^{\circ} \mathrm{C}$ (or between $20-80^{\circ} \mathrm{C}$ ) at a heating rate of $0.5^{\circ} \mathrm{C} / \mathrm{min}$ (up-scan). A $5 \mathrm{mmol} / 1 \mathrm{NaCl}$ solution was used as reference sample, as all samples were prepared in this media. The mass of the sample and the reference were kept constant, at $802 \pm 1 \mathrm{mg}$. Data acquisition and analysis were done using the Setsoft software (Setaram). Samples of DNA + DPPC with different $\mathrm{Zn}^{2+}$ concentrations were analyzed. The enthalpy of the phase transition was obtained from the area under the transition peak using a linear baseline, after subtraction of the blank experiment $(\mathrm{NaCl}$ solution on both the sample and reference sides). The temperature of phase transition was considered as that of the peak maximum (or of each peak maxima) in the heat capacity vs. temperature plot.

The temperature of the gel - liquid-crystal phase transition of DPPC in $\mathrm{ZnCl}_{2}$ solutions was determined by turbidimetry. Measurements were performed on a diode array spectrophotometer 8452A (Hewlett Packard, USA) within the wavelength range $190-820 \mathrm{~nm}$, using $1 \mathrm{~cm}$ quartz cells. The temperature control was provided by Peltier plates (Agilent Technologies, Germany). During temperature scans, the samples were heated at $0.5^{\circ} \mathrm{C} / \mathrm{min}$ with hold time $1 \mathrm{~min}$. Experimental data were processed according to Kotalová et al. (2008).

SAXD and wide-angle X-ray diffraction (WAXD) synchrotron radiation diffraction experiments were performed at the soft-condensed matter beam line A2 at HASYLAB (DESY, Hamburg, Germany). The evacuated double-focusing camera was equipped with two linear delay line readout detectors. The SAXD detector was calibrated using rattail collagen (Roveri et al. 1980) and the WAXD detector by tripalmitin (Chapman 1962). The sample was equilibrated at each selected temperature for $5 \mathrm{~min}$ before exposure to radiation. Each diffraction peak of SAXD region was fitted with a Lorentzian above a linear background.

The SANS experiments were performed on the PAXE spectrometer in LLB (CEA Saclay, France). The sample to detector distance was $2.75 \mathrm{~m}$ and the neutron wavelength was $\lambda=6 \AA(\Delta \lambda / \lambda=10 \%)$ covering the scattering vector range $0.16-2.24 \mathrm{~nm}^{-1}$. The acquisition time for one sample was 30 min. The normalized SANS intensity $I(q)$ as a function of the scattering vector $q$ was obtained as described previously (Kučerka et al. 2003).

\section{Results and Discussion}

Zinc is a divalent transition metal cation interacting readily with neutral phospholipid bilayers, as well as with DNA polyanion. Generally, in a system DNA, DPPC and $\mathrm{ZnCl}_{2}$ one must consider the following binding events (schematic):

$$
\mathrm{DNA}+\mathrm{DPPC}+\mathrm{Zn}^{2+} \longrightarrow\left\{\begin{array}{l}
\mathrm{DPPC}+\mathrm{Zn}^{2+} \\
\mathrm{DNA}+\mathrm{DPPC}+\mathrm{Zn}^{2+} \\
\mathrm{DNA}+\mathrm{Zn}^{2+}
\end{array}\right.
$$

Zwiterionic phospholipids in a solution of divalent metal cations spontaneously form vesicles with a positive surface charge. For example, $1 \mathrm{mmol} / \mathrm{l}$ solution of $\mathrm{CaCl}_{2}$ promotes the formation of DPPC unilamellar vesicles (Inoko et al. 1975; Akashi et al. 1998; Uhríková et al. 2007b). Cationic vesicles interact electrostatically with DNA polyanion, forming aggregates. The interaction is rapid, and takes place during the aggregation process, both phospholipid and DNA undergoing a complete topological transformation into compact quasi-spherical particles with $\sim 0.2 \mathrm{~mm}$ diameter. They can easily form string-like colloidal aggregates, having an ordered structure (Gershon et al. 1993; Koltover et al. 1999). Generally, divalent cations mediate DNA binding to the neutral phospholipids forming temperature stable aggregates as described shortly in the introduction. However, in the case of $\mathrm{Zn}^{2+}$, due to its high affinity to the zwitterionic phospholipid headgroups as well as to DNA one may find a completely different scenario.

\section{DSC}

Salmon sperm DNA denatures at $87.5^{\circ} \mathrm{C}$ in $0.15 \mathrm{~mol} / \mathrm{l} \mathrm{NaCl}$ and $0.015 \mathrm{~mol} / \mathrm{l}$ sodium citrate (Marmur and Doty 1962). When performing experiments using only with DNA or $\left(\mathrm{DNA}+20 \mathrm{mmol} / \mathrm{l}\right.$ of $\mathrm{ZnCl}_{2}$ ) in the temperature range of $20-80^{\circ} \mathrm{C}$, we did not observe any excess heat capacity.

The calorimetric profile of multilamellar DPPC liposomes (Fig. 1, bottom plot) shows a well defined pre-transition and a cooperative main transition, with a $T_{p}=35.8 \pm 0.5^{\circ} \mathrm{C}$ corresponding to the temperature of pre-transition, $\left(L_{\beta} \rightarrow P_{\beta}\right)$, and the main phase transition from gel to liquid-crystalline phase $\left(P_{\beta} \rightarrow L_{\alpha}\right)$ presenting a temperature $T_{m}=42.1 \pm 0.5^{\circ} \mathrm{C}$. The associated enthalpies are $0.71 \pm 0.5 \mathrm{kcal} / \mathrm{mol}$ for the pretransition and $6.9 \pm 0.5 \mathrm{kcal} / \mathrm{mol}$ for the main phase transition. The obtained results are in agreement (within uncertainty) with values reported in the literature, such as $34.4 \pm$ $2.5^{\circ} \mathrm{C}$ with $\Delta H=1.3 \pm 1 \mathrm{kcal} / \mathrm{mol}$ for the pre-transition, and $41.3 \pm 1.8^{\circ} \mathrm{C}$ with $\Delta H=8.2 \pm 1.4 \mathrm{kcal} / \mathrm{mol}$ for the main phase transition, as summarized in Konyova and Caffrey (1998). DNA affects only slightly the thermodynamic parameters of DPPC. We found $T_{p}=35.5 \pm 0.5^{\circ} \mathrm{C}$ and $T_{m}=42.0 \pm 0.5^{\circ} \mathrm{C}$ 


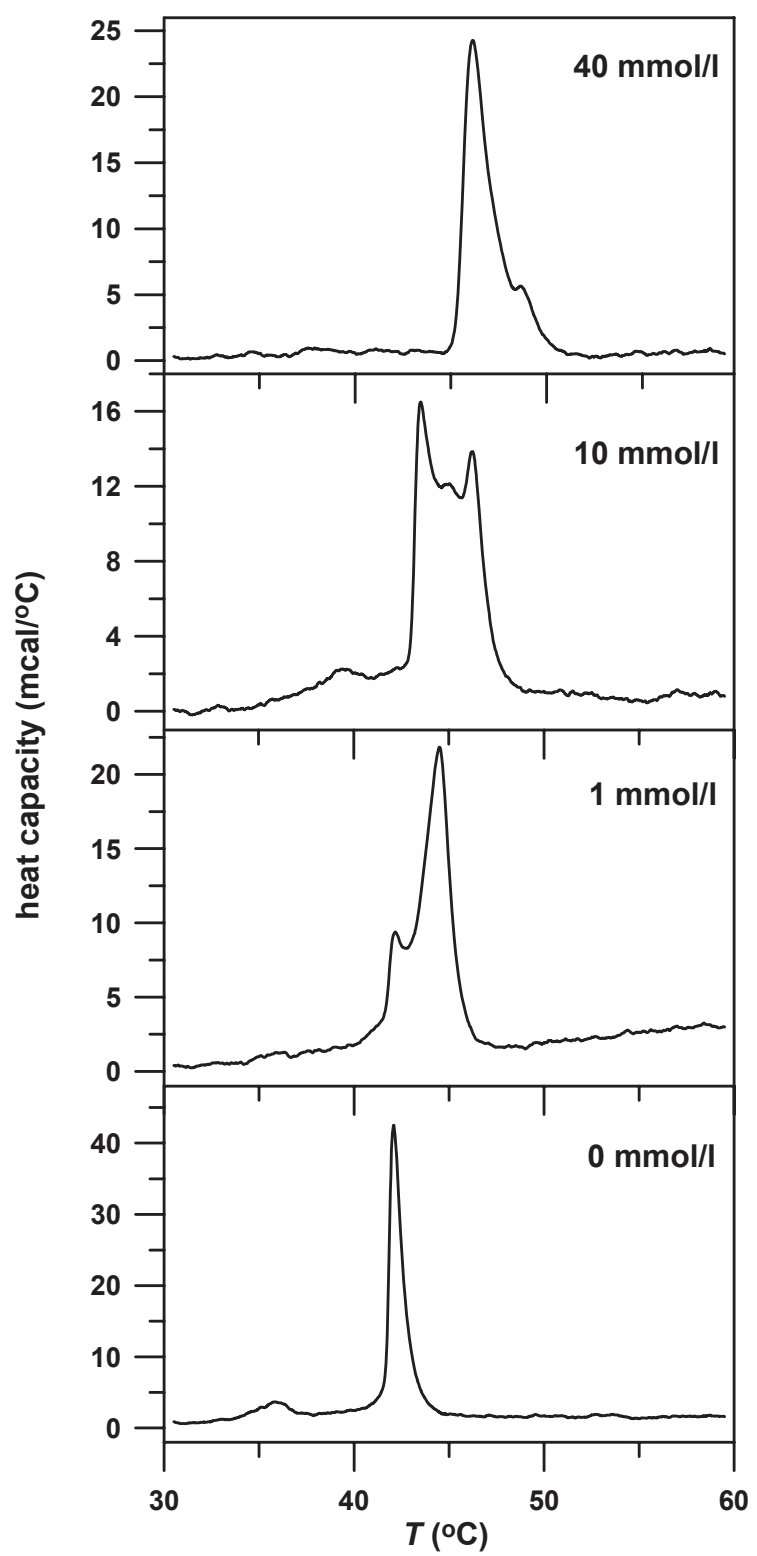

Figure 1. DSC profiles of DPPC vesicles, and DPPC : DNA $=3: 1$ $\mathrm{mol} /$ base mixtures in $\mathrm{ZnCl}_{2}$ solutions of different concentrations. A scanning rate of $0.5^{\circ} \mathrm{C} / \mathrm{min}$ was used throughout.

for the pre- and main transitions in DNA : DPPC $=1: 3$ base/mol, respectively. Zinc, on the other hand, as observed by turbidimetry, increases the DPPC main phase transition temperature, depending on its concentration, as documents in Fig. 2A (empty diamonds).

The DSC thermograms of some DNA $+\mathrm{DPPC}+\mathrm{ZnCl}_{2}$ mixtures at different $\mathrm{ZnCl}_{2}$ concentration are shown in Fig. 1. They always exhibit two well defined maxima, which temperature varies with $\mathrm{ZnCl}_{2}$ concentration. Fig. $2 \mathrm{~A}$ shows the temperature of the obtained maxima as a function of

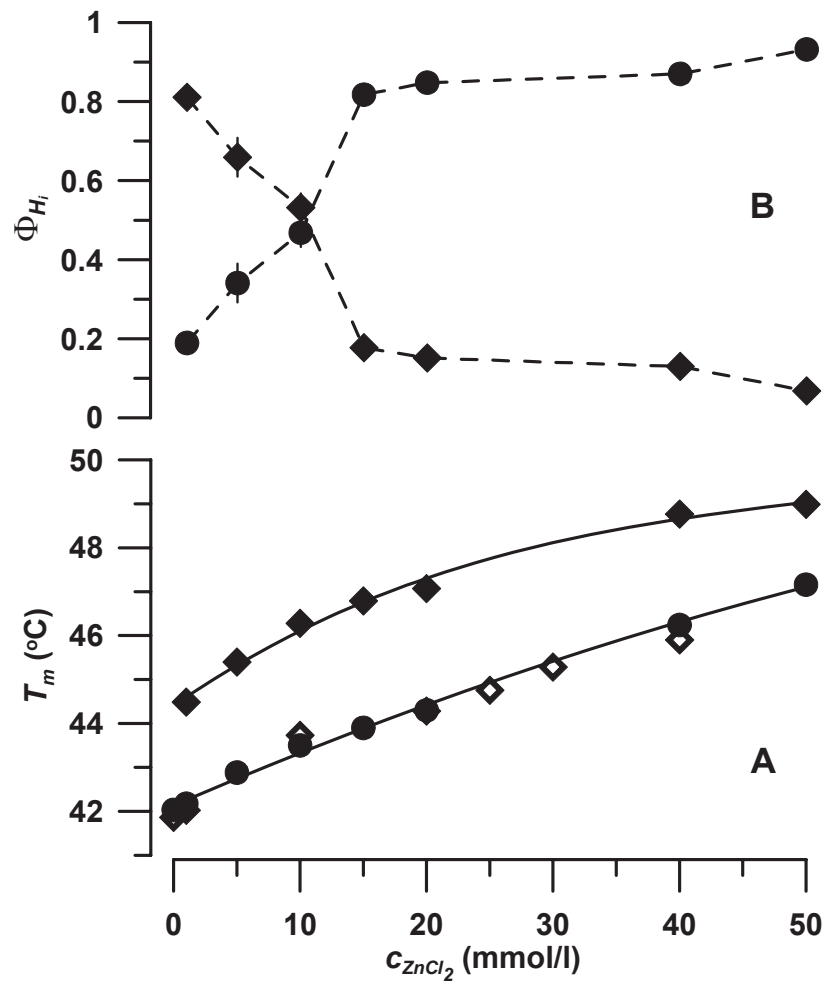

Figure 2. A. Temperature $\left(T_{m}\right)$ of the gel - liquid-crystal phase transition of DPPC as a function of $\mathrm{ZnCl}_{2}$ concentration $\left(\mathrm{c}_{\mathrm{ZnCl} 2}\right)$ for DPPC $+\mathrm{Zn}^{2+}$ vesicles (empty diamonds), and in DNA + DPPC $+\mathrm{Zn}^{2+}$ mixture: $L_{P C}$ phase (full circles), $L_{D N A+P C}$ phase (full diamonds). B. The enthalpy fraction $\Phi_{H i}$ of individual phases $L_{i}$ $(\mathrm{i}=\mathrm{PC}, \mathrm{DNA}+\mathrm{PC})$ vs. $\mathrm{ZnCl}_{2}$ concentration.

$\mathrm{ZnCl}_{2}$ concentration. The first peak was identified as the enthalpy related to the gel - liquid-crystal phase transition of DPPC $+\mathrm{Zn}^{2+}, \Delta H_{P C}$. This assignment was confirmed by the independent turbidimetry measurements on DPPC + $\mathrm{Zn}^{2+}$ mixtures, with the obtained temperatures in excellent agreement with ones derived from calorimetry (Fig. 2A). The second peak corresponds to the enthalpy $\triangle H_{P C+D N A}$ related to the phase transition of the lipid bound in the aggregate $\mathrm{DNA}+\mathrm{DPPC}+\mathrm{Zn}^{2+}$. To quantify the relative changes in the volume fraction of individual phases, we express the enthalpy fraction $\Phi_{H i}$ :

$$
\Phi_{H i}=\frac{\Delta H_{i}}{\Delta H_{t o t}}
$$

where $\Delta H_{i}$ is the enthalpy of $i$-th phase, $i=\mathrm{PC}, \mathrm{PC}+\mathrm{DNA}$ and $\Delta H_{\text {tot }}$ is the total enthalpy. The $\Delta H_{i}$ of $i$-th phase as well as the total enthalpy were determined by integration of the calorimetric profile using the Setaram software. Relative changes in the enthalpy of individual phases as a function of $\mathrm{ZnCl}_{2}$ concentration are depicted in Fig. 2B. As shown 
there, the volume fraction of lipid involved in the DNA + $\mathrm{DPPC}+\mathrm{Zn}^{2+}$ phase decreases significantly with increasing zinc concentration.

According to Binder et al. (2001), $\mathrm{Zn}^{2+}$ bridges between neighboring zwitterionic lipid molecules, forming a complex lipid : $\mathrm{Zn}^{2+}=2: 1$, reaching the ratio $1: 1$ at saturation. The binding site of $\mathrm{Zn}^{2+}$ to the lipid molecules is the negative charged phosphate group of $\mathrm{P}^{-}-\mathrm{N}^{+}$dipole of the phospholipid headgroup. The electronic structure of zinc is different from that of divalent alkali earth metal ions. Zinc cation possesses a higher affinity to electronegative groups (Gresh and Šponer 1999), and therefore also other electronegative moieties such as ester oxygens and/or carbonyl groups of the lipid headgroup can be directly involved in complex formation. The interaction of phospholipid headgroups with $\mathrm{Zn}^{2+}$ is conveniently described by a hydrated zinc-phosphate complex, which key energy contribution has a more covalent than electrostatic nature (Binder et al. 2001). The binding of divalent metal cations is accompanied by a conformational change of the phospholipid headgroups resulting in the reduction of the molecular area and in the hydration of the headgroup (Huster et al. 1999; Uhríková et al. 2008). This corresponds well to the effect of divalent metal cations on the thermotropic chain melting transition of phospholipids. For example, the temperature of the gel - liquid-crystal phase transition of DPPC increases from 41.4 to $44.2^{\circ} \mathrm{C}$ with increasing concentration of $\mathrm{CaCl}_{2}(0-300 \mathrm{mmol} / \mathrm{l})$ (Aruga et al. 1985). Fig. $2 \mathrm{~A}$ documents the increase in $\sim 5^{\circ} \mathrm{C}$ in the phase transition temperature for DPPC in $50 \mathrm{mmol} / 1 \mathrm{ZnCl}_{2}$, likely due to the above mentioned strong binding of the cation.

Aggregates DNA + DPPC $+\mathrm{Zn}^{2+}$ are formed when $\mathrm{Zn}^{2+}$ cations mediate DNA-DPPC binding. The binding of cations induce changes in the $\mathrm{P}^{-}-\mathrm{N}^{+}$dipole conformation. The positive side of the dipole is pushed out into the aqueous phase (Scherer and Seelig 1989), and, due to electrostatic interaction with the negatively charged phosphate groups of DNA, the aggregate is formed. However, in the presence of negatively charged polyelectrolytes, the cation binding of the lipid - polyelectrolyte complex is drastically enhanced, as shown by Huster and Arnold (1998) for DMPC/dextran sulfates (DS)/calcium system. In addition to the formation of calcium bridges between lipid's phosphate groups and the sulfate groups of DS, the authors suggest the accumulation of calcium in the diffuse double layer at the lipid-DS plane, according to the Gouy-Chapman theory.

In our system, the low concentration of zinc supports the formation of DNA $+\mathrm{DPPC}+\mathrm{Zn}^{2+}$ aggregates because the cations are "consumed" in DNA-DPPC binding. Fig. $2 \mathrm{~B}$ indicates a significant reduction in the volume fraction of DNA + DPPC $+\mathrm{Zn}^{2+}$ phase with increasing $\mathrm{Zn}^{2+}$ concentration, up to $20 \mathrm{mmol} / \mathrm{l}$ of $\mathrm{ZnCl}_{2}$. The total molar balance of $\mathrm{Zn}^{2+}$ : DPPC $\sim 3$ at this concentration indicates full saturation of DPPC binding sites, and that formation of the diffuse double layer can take place. Due to the saturation of zinc in the system, negative charges of DNA phosphate fragments are neutralized. Kejnovsky and Kypr (1998) have found that milimolar concentrations of zinc cause DNA sedimentation.

\section{SANS experiments}

For dispersions of monodisperse centrosymmetric particles, the SANS intensity is given by

$$
I(q)=N_{p} \cdot P(q) \cdot S(q)
$$

where $q$ is the scattering vector $q=4 \pi \sin \theta / \lambda, 2 \theta$ is the scattering angle, $N_{P}$ the number density of particles, $P(q)$ their form factor and $S(q)$ the interparticle structure factor. The interparticle structure factor $S(q)$ is approximately equal to 1 for dilute and weakly interacting particles, what is a good approximation for unilamellar vesicles at phosphatidylcholine concentrations $<2 \mathrm{wt} \%$ (Knoll et al. 1981; Nawroth et al. 1989). The model of weakly interacting particles describes well unilamellar vesicles prepared by extrusion (Balgavý et al. 1998). A typical SANS curve of unilamellar vesicles prepared by extrusion is shown in Fig. 3. Indeed, we do not observe any correlation peak in the scattering intensity in the studied $q$ range. Unilamellar vesicles are formed spontaneously when the surface charge density is higher than $1-2 \mu \mathrm{C} / \mathrm{cm}^{2}$ (Hauser 1993). Fig. 3 (empty squares) shows unilamellar DPPC vesicles formed spontaneously in $20 \mathrm{mmol} / 1 \mathrm{ZnCl}_{2}$.

In first approximation, unilamellar vesicles are hollow spheres with the lipid bilayer shell separating the inside and outside aqueous compartments. The extruded liposomes are spherical with a broad distribution of radii (MacDonald et al. 2001), and the scattered intensity can be fitted by a model of randomly oriented planar bilayers (Balgavý et al. 1998 and references therein). For such particles, the factor $P(q)$ can be calculated by the one-dimensional Fourier integral of the coherent neutron scattering length density. According to the Guinier approximation, at values of $q$ large as compared with the inverse of the radii of the vesicles (Glatter and Kratky 1983; Feigin and Svergun 1987), Eq. (2) can be written as:

$$
I(q)=C t e \cdot q^{-2} \exp \left(-q^{2} R_{g}^{2}\right)
$$

where Cte is a constant and $R_{g}$ is the radius of gyration of a flat bilayer. Eq. (3) is valid for finite size objects when $L^{-1} \leq$ $q \leq R_{g}^{-1}$, where $L$ is the largest dimension size of the object. The thickness of the two-dimensional planar sheet $d_{g}$ can be obtained from $R_{g}$ as (Glatter and Kratky 1983; Feigin and Svergun 1987):

$d_{g}^{2} \cong 12 R_{g}^{2}$ 
Table 1. Structural parameters of DPPC bilayer

\begin{tabular}{|l|c|c|c|c|c|c|}
\hline & $\begin{array}{c}c_{Z n C l 2} \\
(\mathrm{mmol} / \mathrm{l})\end{array}$ & $\begin{array}{c}T \\
\left({ }^{\circ} \mathrm{C}\right)\end{array}$ & $\begin{array}{c}R_{g}{ }^{2} \\
\left(\mathrm{~nm}^{2}\right)\end{array}$ & $\begin{array}{c}d_{g} \\
(\mathrm{~nm})\end{array}$ & $\begin{array}{c}q_{0} \\
\left(\mathrm{~nm}^{-1}\right)\end{array}$ & $\begin{array}{c}d_{D N A+P C} \\
(\mathrm{~nm})\end{array}$ \\
\hline DPPC & - & 50 & $1.37 \pm 0.05$ & $4.05 \pm 0.08$ & - & - \\
\hline DPPC & 20 & 50 & $1.73 \pm 0.01$ & $4.56 \pm 0.01$ & - & - \\
\hline DNA + DPPC & 20 & 50 & $1.68 \pm 0.02$ & $4.49 \pm 0.03$ & $0.83 \pm 0.01$ & $7.57 \pm 0.09$ \\
\hline DNA + DPPC & 5 & 50 & $1.37 \pm 0.05$ & $4.05 \pm 0.08$ & $0.82 \pm 0.01$ & $7.66 \pm 0.09$ \\
\hline DNA + DPPC & 30 & 50 & $1.87 \pm 0.03$ & $4.74 \pm 0.03$ & - & - \\
\hline DNA + DPPC & 5 & 20 & $1.39 \pm 0.07$ & $4.08 \pm 0.10$ & $0.760 \pm 0.002$ & $8.27 \pm 0.02$ \\
\hline
\end{tabular}

The Kratky-Porod plot $\ln \left(I q^{2}\right)$ vs. $q^{2}$ is usually used to determine easily the $R_{g}$ (Fig. 3, inset A), then $d_{g}$ in the $q$ range $0.32 \leq q \leq 0.89 \mathrm{~nm}^{-1}$ are given in the Table 1 . The $d_{g}$ value obtained for unilamellar DPPC vesicles corresponds well to our previous experiments and to the data from literature (Balgavý et al. 2001 and reference therein). In presence of $20 \mathrm{mmol} / 1 \mathrm{ZnCl}_{2}$, we observe a small increase in the lipid bilayer thickness. Due to binding to the zwitterionic phospholipid bilayer, calcium induces structural changes, affecting thickness, area per lipid molecule as well as hydration (Uhríková et al. 2007b, 2008). Zinc affects the DPPC lipid bilayer thickness in a similar way, as indicates the $d_{g}$ of DPPC in $20 \mathrm{mmol} / 1 \mathrm{ZnCl}_{2}$.

Next SANS curve depicted on Fig. 3 corresponds to the $\mathrm{DNA}+\mathrm{DPPC}$ mixture in $5 \mathrm{mmol} / \mathrm{l} \mathrm{ZnCl}_{2}$, at $50^{\circ} \mathrm{C}$. The observed correlation peak with the maximum at $q \sim 0.8$ $\mathrm{nm}^{-1}$ indicates an organized structure due to multilamellar stacking. Part of the lipid is bound to DNA, forming a DNA + $\mathrm{DPPC}+\mathrm{Zn}^{2+}$ aggregate, as indicate DSC experiments. The observed peak is the first order reflection due to lipid bilayer stacking in a condensed lamellar phase of the aggregate, as confirmed by SAXD experiments described below. To analyze the scattering profile, one must assume an interparticle structure factor $S(q)$ :

$$
I(q)=C t e \cdot q^{-2} \cdot \exp \left(-q^{2} R_{g}^{2}\right) \cdot S(q)
$$

Imposing Gaussian shape for $S(q)$, we obtain for the scattering intensity:

$$
I(q)=C t e \cdot q^{-2} \cdot \exp \left(-q^{2} R_{g}^{2}\right) \cdot\left\{1+k \exp \left[-0.5\left(\frac{q-q_{0}}{\sigma_{G}}\right)^{2}\right]\right\}
$$

where $q_{0}$ is the position of the peak maximum, $\sigma_{G}$ is the width of the Gaussian, and $k$ corresponds to the amount of multilamellar structures. We separated the form and structure factor analytically; the obtained parameters $\left(R_{g}{ }^{2}\right.$ and $q_{0}$ ) are given in Table 1. Fig. 3, inset B shows the obtained structure factors $S(q)$ vs. $q$. Full lines in Fig. 3 represent the scattered intensities fitted by Eq. (6). In both high and middle $q$-regions, the experimental data are correctly fit- ted. Instead, the shape of SANS curve in the low $q$-region is affected by the size of unilamellar vesicles and their polydispersity (Kučerka et al. 2004) that were not included in our analysis. With increasing concentration of zinc, the intensity of the correlation peak decreases. The SANS

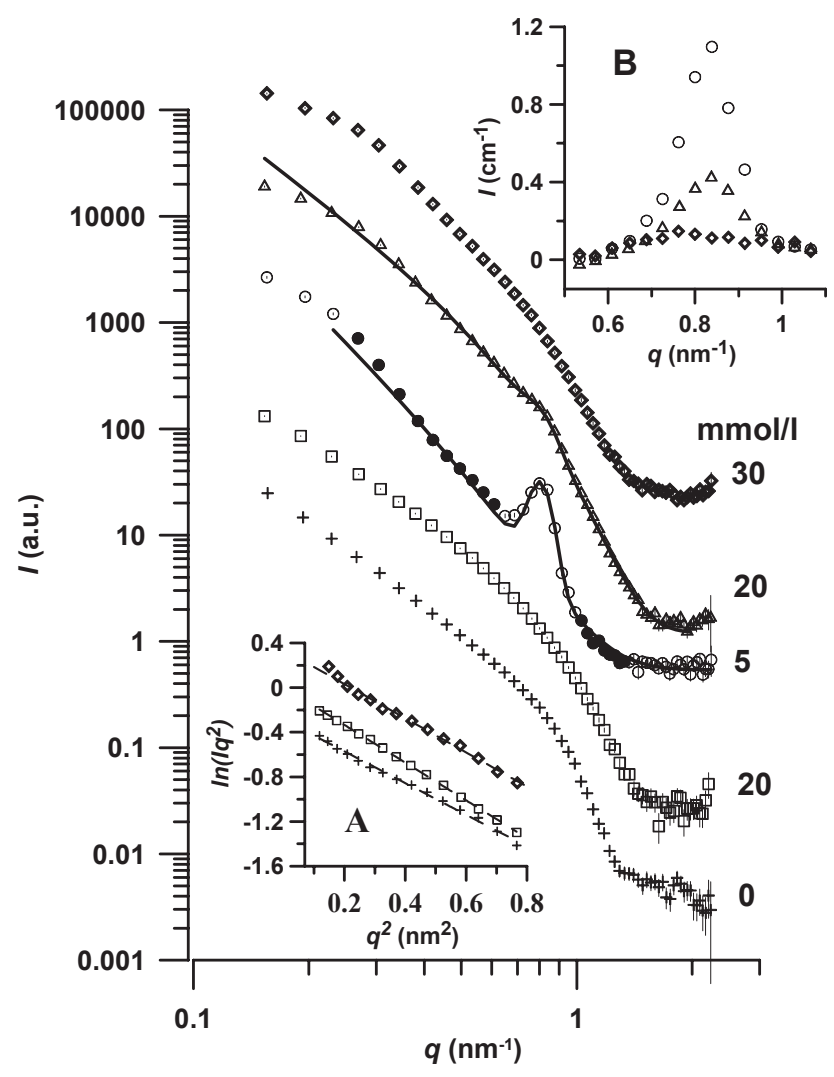

Figure 3. SANS intensity, $I(q)$, for DPPC unilamellar vesicles $(+, \square)$, and DPPC : DNA $=3: 1 \mathrm{~mol} /$ base mixture at given $\mathrm{ZnCl}_{2}$ concentrations, at $50^{\circ} \mathrm{C}$. Inset A. Kratky-Porod plot for curves of DPPC vesicles (+), DPPC in $20 \mathrm{mmol} / \mathrm{l} \mathrm{ZnCl}_{2}(\square)$ and DNA + DPPC in $30 \mathrm{mmol} / 1 \mathrm{ZnCl}_{2}(\diamond)$. Lines represent the best fits. Inset B. $S(q)-1$ extracted analytically from curves of DNA + DPPC mixture at $\mathrm{ZnCl}_{2}$ concentrations: $5 \mathrm{mmol} / \mathrm{l}(\mathrm{O}), 20 \mathrm{mmol} / \mathrm{l}(\triangle), 30$ $\mathrm{mmol} / \mathrm{l}(\diamond)$. Full points were used for the determination of $R_{g}{ }^{2}$. 


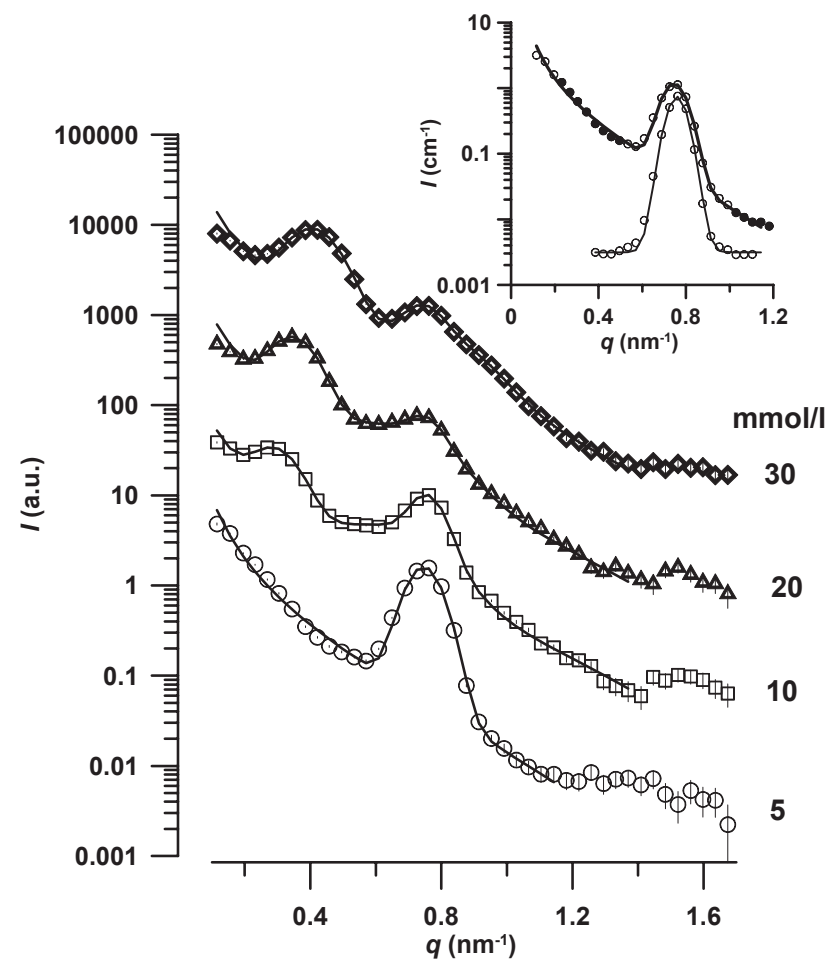

Figure 4. SANS intensity, $I(q)$, for DPPC : DNA $=3: 1 \mathrm{~mol} / \mathrm{base}$ mixture at given $\mathrm{ZnCl}_{2}$ concentrations, at $20^{\circ} \mathrm{C}$. Inset: separation of the form and structure factors. Full points were used for the determination of $R_{g}^{2}$. Full lines represent the best fits.

curve of DNA + DPPC aggregate at $30 \mathrm{mmol} / 1 \mathrm{ZnCl}_{2}$ does not show any correlation peak (Fig. 3). The Kratky-Porod plot (Fig. 3, inset A) as well as data in Table 1 document a "dissolution" of the aggregate into $\mathrm{DPPC}+\mathrm{Zn}^{2+}$ unilamellar vesicles and DNA $+\mathrm{Zn}^{2+}$. The contrast between $\mathrm{DNA}+\mathrm{Zn}^{2+}$ and $\mathrm{D}_{2} \mathrm{O}$ at the used DNA concentration is small and thus its contribution to the SANS intensity is negligible. DSC experiments indicate a small fraction of DPPC bound in the aggregates with the phase transition at $T_{m} \sim 48^{\circ} \mathrm{C}$. SANS experiments were performed at $50^{\circ} \mathrm{C}$, samples were equilibrated at each temperature at least 30 min before exposition. Our analysis of the SANS curve indicates "zero" intensity of the correlation peak as shows Fig. 3 (inset B). However, the shape of the SANS curve is slightly deformed in comparison to that from unilamellar vesicles (Fig. 3), resulting probably from a deformation of vesicles due to DNA binding DNA at their surface.

Before heating to $50^{\circ} \mathrm{C}$, the samples were measured at $20^{\circ} \mathrm{C}$, when the lipid is in gel state. The representative SANS curves of DNA $+\mathrm{DPPC}+\mathrm{Zn}^{2+}$ mixtures shown in Fig. 4 . The scattering profile of the mixture in $5 \mathrm{mmol} / \mathrm{ZnCl}_{2}$ is similar to that observed at $50^{\circ} \mathrm{C} . R_{g}{ }^{2}$, as well as the position of the peak maximum, $q_{0}$, are given in Table 1 . At high concentra-

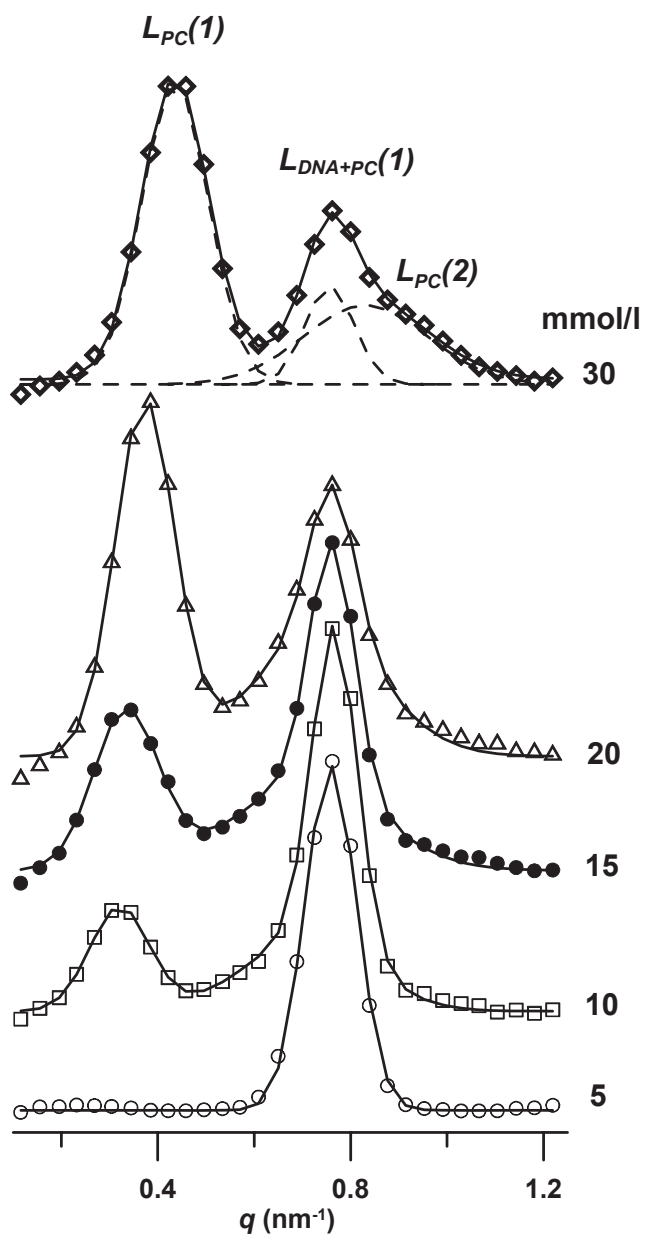

Figure 5. Structure factor, $S(q)$, for $L_{P C}$ and $L_{D N A+P C}$ phases of the DNA + DPPC mixture at given $\mathrm{ZnCl}_{2}$ concentrations $\left(20^{\circ} \mathrm{C}\right)$. Full lines represent the fits. Dashed lines show the deconvolution of $S(q)$ into the reflections (of the first and second order) of $L_{P C}$ and $L_{D N A+P C}$ phase.

tions of zinc, SANS curves of DNA $+\mathrm{DPPC}+\mathrm{Zn}^{2+}$ mixtures show, in addition to the peak related to the DPPC stacking in a condensed lamellar phase, another peak at low $q$ ( $q \sim$ $\left.0.3 \mathrm{~nm}^{-1}\right)$. Due to the scattering of DPPC $+\mathrm{Zn}^{2+}$ vesicles, both peaks are superimposed. We separated analytically the structure and form factor with the aim to understand the structural organization of the mixture in the gel phase. The peak at low $q$ does not allow a good evaluation of form factor with Eq. (3). As a compromise, we imposed the values $\left(R_{g}{ }^{2}=\right.$ $1.39 \mathrm{~nm}^{2}$ and Cte $=0.0006$ ), obtained from the analysis of $\mathrm{DNA}+\mathrm{DPPC}$ in $5 \mathrm{mmol} / \mathrm{l} \mathrm{ZnCl}_{2}$ (at $20^{\circ} \mathrm{C}$ ) to extract the curves related to the structure factor of mixtures prepared at high concentrations of $\mathrm{Zn}^{2+}$. The curves obtained from the analysis are shown in Fig. 5. The peaks were identified as the first order reflections of two lamellar phases: a phase 


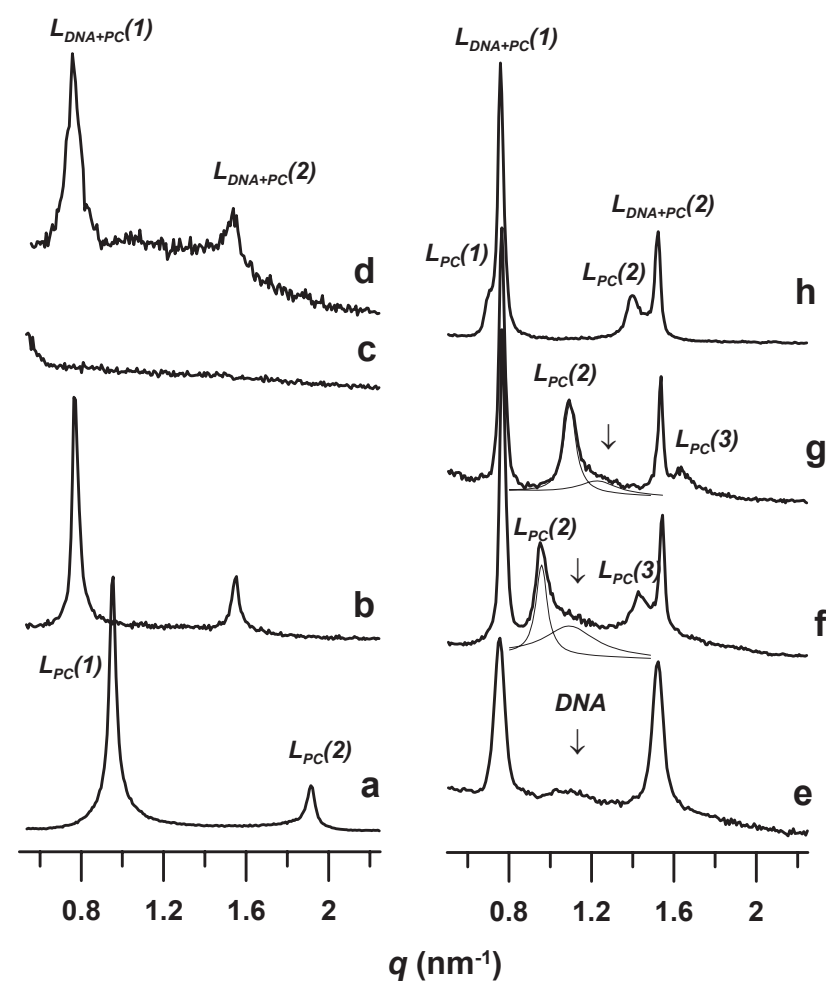

Figure 6. SAX diffractograms of multilamellar DPPC vesicles, $20^{\circ} \mathrm{C}$ (a), and DNA + DPPC mixtures at: b) $20 \mathrm{mmol} / 1 \mathrm{ZnCl}_{2}\left(I_{S}=\right.$ $65 \mathrm{mmol} / \mathrm{l}) 20^{\circ} \mathrm{C}$; c) at $60^{\circ} \mathrm{C}$; d) at $20^{\circ} \mathrm{C}$, after heating-cooling cycles; e) $2.5 \mathrm{mmol} / \mathrm{l} \mathrm{ZnCl}\left(I_{S}=95.5 \mathrm{mmol} / \mathrm{l}\right) 20^{\circ} \mathrm{C}$; f) $20 \mathrm{mmol} / 1 \mathrm{ZnCl}_{2}$ $\left(I_{S}=122.2 \mathrm{mmol} / \mathrm{l}\right) 20^{\circ} \mathrm{C}$; g) $20 \mathrm{mmol} / \mathrm{Z} \mathrm{ZnCl}_{2}\left(I_{S}=160 \mathrm{mmol} / \mathrm{l}\right)$ $20^{\circ} \mathrm{C}$; h) $20 \mathrm{mmol} / 1 \mathrm{ZnCl}_{2}\left(I_{S}=231 \mathrm{mmol} / \mathrm{l}\right) 20^{\circ} \mathrm{C}$

related to $\mathrm{DPPC}+\mathrm{Zn}^{2+}, L_{P C}$, with a decreasing periodicity $d_{P C} \sim 20-12 \mathrm{~nm}$ as a function of $\mathrm{ZnCl}_{2}$ concentration, and a condensed lamellar phase, $L_{D N A+P C}$, with DNA strands located between the DPPC bilayers showing the periodicity $d_{D N A+P C} \sim 8.3 \mathrm{~nm}$. The repeat distances (together with results from SAXD experiments) are summarized in Fig. 7, expressed as a function of $\mathrm{ZnCl}_{2}$ concentration and/or the ionic strength of the solution $\left(I_{S}\right)$ :

$$
I_{S}=\frac{1}{2} \sum_{i} c_{i} z_{i}^{2}
$$

where $c_{i}$ is the concentration and $z_{i}$ is the charge number of $i$-th ion in the solution.

To summarize SANS experiments: at low concentration of zinc, the DNA + DPPC $+\mathrm{Zn}^{2+}$ aggregates are stable against to heating up to $50^{\circ} \mathrm{C}$. Concentrations of zinc above $20 \mathrm{mmol} / \mathrm{l}$, do not promote the formation of a DNA $+\mathrm{DPPC}+\mathrm{Zn}^{2+}$ phase in the DPPC liquid-crystalline state. We observe the dissolution of the aggregates into DPPC $+\mathrm{Zn}^{2+}$ vesicles and $\mathrm{DNA}+\mathrm{Zn}^{2+}$ at $50^{\circ} \mathrm{C}$, e.g. DNA + DPPC in $20 \mathrm{mmol} / 1 \mathrm{ZnCl}_{2}$ shows a small fraction of the lipid bound in the aggregates at $50^{\circ} \mathrm{C}$, however, no organized structure at $60^{\circ} \mathrm{C}$ as resulted from SAXD experiments (see below, and Fig. 6c).

In the gel state of the lipid, we observe a coexistence of two lamellar phases $L_{P C}$ and $L_{D N A+P C}$ when the concentration of zinc exceeds $5 \mathrm{mmol} / \mathrm{l}$. The periodicity of the $L_{P C}$ phase is modulated with increasing concentration of zinc. The effect of divalent cations, $\mathrm{Ca}^{2+}$ and $\mathrm{Mg}^{2+}$, on the long-range organization of the DPPC bilayers was studied experimentally in the pioneering work of Inoko et al. (1975), and interpreted using models for electrostatic cation - dipole interaction (Izumitani 1994, 1996). Yamada et al. (2005) reported recently that the phase behaviour of DPPC as a function of $\mathrm{CaCl}_{2}$ concentration is different in the gel and liquid-crystalline phase. Their experiments revealed a so called "unbound state" of DPPC bilayers (e.g. unilamellar vesicles) up to $\sim 50 \mathrm{mmol} / \mathrm{l} \mathrm{CaCl}_{2}$ at $20 \mathrm{wt} \%$ of DPPC in liquid-crystalline phase, and this phenomenon was dependent on the DPPC concentration. In the gel phase, the DPPC $+\mathrm{Ca}^{2+}$ mixture forms a lamellar phase with decreasing periodicity $\sim 33-6.5 \mathrm{~nm}$ in the concentration range $4-400 \mathrm{mmol} / \mathrm{l}$ of $\mathrm{CaCl}_{2}$. This behaviour is attributable to the fact that the steric repulsion of lipid bilayers due to undulation is larger in the liquid-crystalline phase than in the gel phase. Our experiments revealed a similar temperature behaviour of the DNA $+\mathrm{DPPC}+\mathrm{ZnCl}_{2}$ mixture when zinc concentration exceeded $20 \mathrm{mmol} / \mathrm{l}$. One can find a disharmony in the $d_{P C}$ periodicity when comparing our data $\left(d_{P C} \sim 20 \mathrm{~nm}\right.$ in $\left.10 \mathrm{mmol} / 1 \mathrm{ZnCl}_{2}\right)$ with data of Yamada et al. (2005) ( $\sim 33 \mathrm{~nm}$ in $4 \mathrm{mmol} / \mathrm{l} \mathrm{CaCl} 2)$. This discrepancy may result from the difference in ion binding (Binder and Zschornig 2002); however, DNA strands not involved in the $L_{D N A+P C}$ phase, and dispersed in $\mathrm{ZnCl}_{2}$ solution may act as an osmotic stressing medium.

\section{$X$-ray diffraction}

The diffraction pattern of multilamellar stacking consists of a number regularly spaced sharp reflections, which can be indexed as the integral orders of Bragg diffraction lines from a one-dimensional crystal with the lattice periodicity along the stacking axis. The structure factors $S(q)$ are related to the electron density distribution of the unit cell in the stacking direction. Our samples were prepared in excess of water. Due to fluctuations of fully hydrated lipid bilayers, the diffractograms usually show 2-3 reflections (see e.g. Nagle and Tristram-Nagle 2000).

SAXD and WAXD experiments were performed to examine the structural organization of the DNA + DPPC + $\mathrm{ZnCl}_{2}$ mixtures in the gel phase. To prove the reliability of the SANS curves analysis, selected samples were measured again by X-ray diffraction. Typical diffractograms are shown in Fig. 6b-d, and discussed below. As it is shown in Fig. 7, structural parameters obtained with both methods agree within the error of analysis. With the aim to understand 


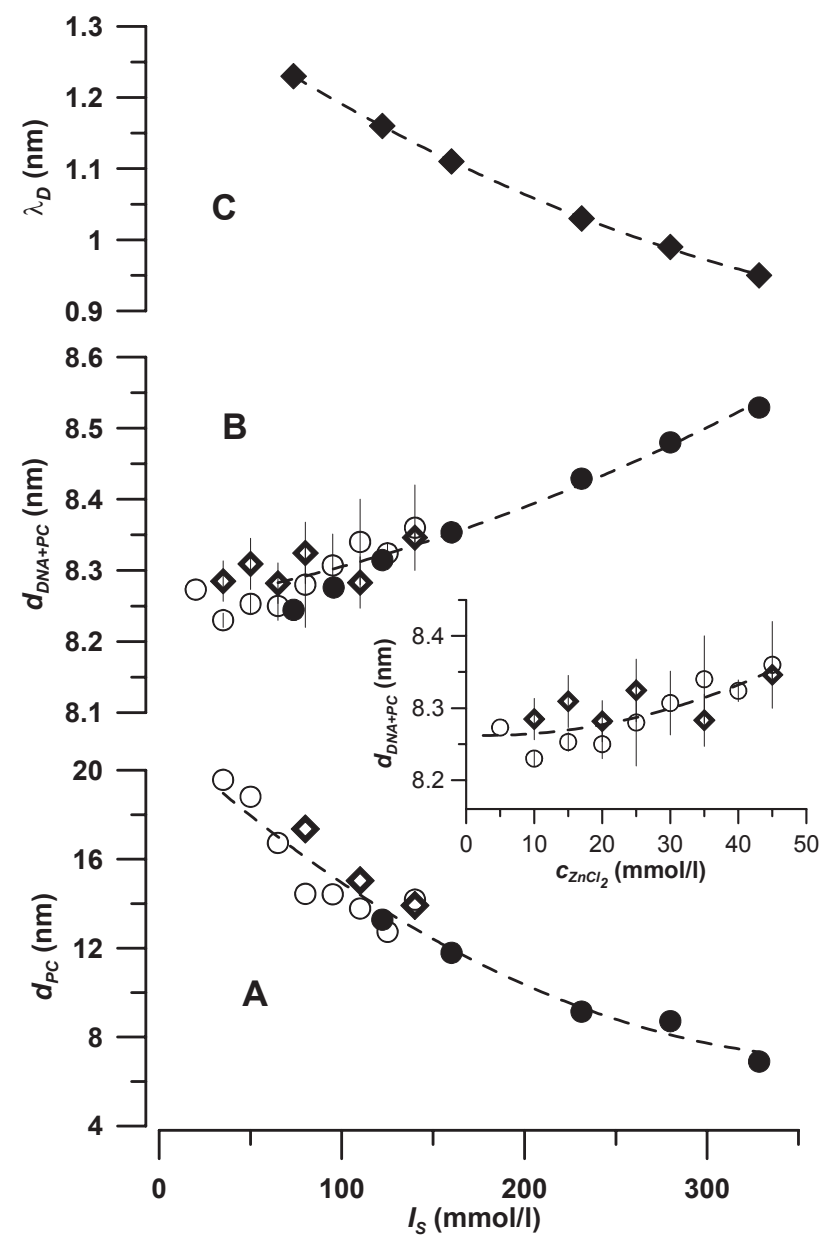

Figure 7. Dependence of the repeat distances $d$ on the ionic strength $I_{S}$ of solutions $\left(20^{\circ} \mathrm{C}\right)$ for phases $L_{P C}(\mathrm{~A})$ and $L_{D N A+P C}(\mathrm{~B})$. Empty circles represent data from SANS; empty diamonds - the same samples measured by SAXD; full circles - DNA + DPPC in $20 \mathrm{mmol} / \mathrm{Z} \mathrm{ZnCl}_{2}$, and ionic strength modulated by $\mathrm{NaCl}$. C. The Debye screening length $\lambda_{D}$ as a function of ionic strength used in our experiments. Inset: the $d_{D N A+P C}$ as a function of $\mathrm{ZnCl}_{2}$ concentration $\left(\mathrm{c}_{\mathrm{ZnCl} 2}\right)$.

what effect plays ionic strength in the structural organization of the mixture, we have prepared an additional set of samples. DNA + DPPC was hydrated in $20 \mathrm{mmol} / 1 \mathrm{ZnCl}_{2}$ at increasing $\mathrm{NaCl}$ concentration to modulate the ionic strength of the solution. The representative diffractograms are given in Fig. $6 \mathrm{f}-\mathrm{h}$.

The SAXD pattern of fully hydrated DPPC at $20^{\circ} \mathrm{C}$ (Fig. 6a) shows the first and the second order reflection $\left(L_{P C}(1)\right.$ and $\left.L_{P C}(2)\right)$ of a lamellar phase with the periodicity $d_{P C}=6.36 \pm 0.01 \mathrm{~nm}$. The WAXD region of all diffractograms (not shown) exhibit patterns typical of either a gel or a liquid-crystalline phase in accord with the phase transition temperatures obtained from DSC experiments.
The diffractograms in Fig. 6b-d correspond to the DNA + DPPC mixture in $20 \mathrm{mmo} / 1 \mathrm{ZnCl}_{2}\left(I_{S}=65 \mathrm{mmol} / \mathrm{l}\right)$ prepared for SANS experiments. Two peaks of the pattern in Fig. $6 \mathrm{~b}$ were identified as the reflections related to the regular packing of lipid bilayers in a condensed lamellar phase $L_{D N A}+P C$ with periodicity $d_{D N A+P C}=8.28 \pm 0.03 \mathrm{~nm}$ (at $\left.20^{\circ} \mathrm{C}\right)$. We do not see any peak related to regular DNA packing between lipid bilayers, as was observed in SAXD of condensed lamellar phase of complexes with cationic amphiphiles (see e.g. Radler et al. 1997; Uhríková et al. 2002). This disorder of the DNA lattice is frequently observed in DNA + phosphatidylcholine aggregates with divalent cations (Francescangeli et al. 2003; McManus et al. 2003) and is caused dominantly by in-plane fluctuations of the DNA strands as analyzed in (Uhríková et al. 2007a). The SANS experiments revealed the dissolution of aggregates in the liquid-crystalline state of DPPC. Only a small volume fraction of the mixture has kept regular packing at $50^{\circ} \mathrm{C}$. The diffractogram in Fig. $6 \mathrm{c}$ has been taken at $60^{\circ} \mathrm{C}$ and the pattern shows no traces of any regular packing in the mixture. Cooling the sample back to the gel phase, the $\mathrm{DNA}+\mathrm{DPPC}+\mathrm{Zn}^{2+}$ condensed lamellar phase is build up again (Fig. 6d). We observed several times this "recovering" of the $L_{D N A+P C}$ phase. As an example, the diffractogram in Fig. $6 \mathrm{~d}$ has been taken at the end of a temperature cycle (in $\left.{ }^{\circ} \mathrm{C}\right):$ 20, 50, 20, 80, 20, 60, 20.

A low concentration of zinc supports the formation of the $L_{D N A+P C}$ phase in the mixture, as revealed by DSC experiments. Fig. 6e shows the diffractogram of DNA + DPPC aggregate at $2.5 \mathrm{mmol} / 1 \mathrm{ZnCl}_{2}\left(I_{S}=95.5 \mathrm{mmol} / \mathrm{l}\right)$. In addition to the two peaks related to the lipid bilayers stacking, a low intensity broad peak, at $q \approx 1.06 \mathrm{~nm}^{-1}$, is identified as evidencing DNA-DNA organization. We have found the interhelical DNA-DNA distance to be $d_{D N A}=5.92 \pm 0.07 \mathrm{~nm}$ at $20^{\circ} \mathrm{C}$. The obtained data correlate well with structural parameters of a gel condensed lamellar phase of DNA + DPPC + $\mathrm{Ca}^{2+}$ aggregates in our previous experiments (Uhríková et al. 2007a). The aggregate was prepared at high ionic strength, $I_{S}=95.5 \mathrm{mmol} / \mathrm{l}$. A marked dependence of $d_{P C}$ on the ionic strength, lead us to test if the maximum at $q \approx 1.06 \mathrm{~nm}^{-1}$ does not correspond to a higher order reflection of the $L_{P C}$ phase. The repeat distance $d$ is given

$$
d=\frac{2 \pi n}{q}
$$

where $q$ is the position of the maximum and $n$ is an order of the reflection. For $q \approx 1.06 \mathrm{~nm}^{-1}$ and $n=1,2$, and 3 one obtains periodicities $5.92,11.86$, and $17.78 \mathrm{~nm}$, respectively. Using the dependence $d_{P C}=f\left(I_{S}\right)$ we find $d_{P C}=15.2 \mathrm{~nm}$ for $I_{S}=95.5 \mathrm{~mol} / \mathrm{l}$, and thus we can conclude that the maximum is not related to the $L_{P C}$ phase.

As follows from our experiments, at low concentration of zinc ( $<20 \mathrm{mmol} / \mathrm{l})$, the repeat distance of condensed lamellar 
phase $d_{D N A+P C} \sim 8.27 \mathrm{~nm}$ is constant within the error, zinc cations mediate binding between DNA and DPPC (Fig. 7, inset). A further increase in the zinc concentration induces the increase in $d_{D N A+P C}$. Along with the $d_{D N A+P C}$ increase we observe a decrease in the repeat distance of $L_{P C}$ phase.

Fig. $6 \mathrm{f}-\mathrm{h}$ show the diffractograms of DNA + DPPC mixtures in $20 \mathrm{mmol} / 1 \mathrm{ZnCl}_{2}$ at different ionic strength. Diffractograms indicate a superposition of two lamellar phases, $L_{D N A+P C}$ and $L_{P C}$. A small asymmetry in the shape of the second order reflections $L_{P C}(2)$ (Fig. 6f,g) could result from a superposition of the DNA-DNA packing related peak (marked by an arrow). Further increase in the ionic strength $\left(I_{S}=231 \mathrm{mmol} / \mathrm{l}\right)$ does not support regular DNA packing (Fig. 6h). The obtained periodicities $d_{P C}$ and $d_{D N A+P C}$ are given in the Fig. 7A,B and offer a complementary information to the SANS data. With increasing $I_{S}$ we observe two opposite effects: the repeat distance $d_{D N A+P C}$ of the DNA + $\mathrm{DPPC}+\mathrm{Zn}^{2+}$ condensed lamellar phase increases showing the total change $\Delta d_{D N A+P C} \sim 0.3 \mathrm{~nm}$, and the repeat distance $d_{P C}$ decreases non-linearly, with $d_{P C} \sim 6.9 \mathrm{~nm}$ at $I_{S}=$ $330 \mathrm{mmol} / \mathrm{l}$ reaching almost the periodicity of pure DPPC $\left(d_{P C} \sim 6.4 \mathrm{~nm}\right)$.

The driving force for mutual condensation of DNA by cationic vesicles to form an ordered, composite phase is the gain in electrostatic free energy. The electrostatic free energy depends on the surface charge densities of the separated macroions, the structure and composition of the condensed phases, and the salt concentration in solution (May et al. 2000). The calculations of the electrostatic free energies of the various structures are based on the Poisson-Boltzmann theory. The system DPPC- $\mathrm{Ca}^{2+}$ was analyzed in this way by (Izumitani 1994; 1996). A detailed analysis of the phase behaviour of DNA, cationic amphiphiles and neutral phospholipids mixtures can be found in Bruinsma and Mashl (1998), Harries et al. (1998), May et al. (2000). If salt is added to the system, the mobile salt ions screen electrostatic interactions between fixed charges along DNA and the $\mathrm{P}^{-}-\mathrm{N}^{+}$ dipole of phospholipid headgroups. This screening is quantified by a Debye screening length (Moore 1972):

$$
\lambda_{D}=\left(\frac{e^{2}}{\varepsilon_{0} \varepsilon_{r} k_{B} T} \sum_{i} \chi_{i} z_{i}^{2}\right)^{-\frac{1}{2}}
$$

where $\varepsilon_{0}, \varepsilon_{r}$ are permitivities, $k_{B}$ is the Boltzmann constant, $T$ is the temperature and, $\chi_{i}$ is the number density of the $i$-th ion with its charge number $z_{i}$. The Debye screening length decreases with increasing concentration, e.g. $\lambda_{D} \sim 5.6-1.2$ $\mathrm{nm}$ for $1-20 \mathrm{mmol} / \mathrm{l} \mathrm{ZnCl}_{2}$ (in $5 \mathrm{mmol} / \mathrm{l} \mathrm{NaCl}$ ) solution, as used in our experiments. Fig. $7 \mathrm{C}$ shows the decrease in $\lambda_{D}$ versus ionic strength of $20 \mathrm{mmol} / \mathrm{ZnCl}_{2}$ solution with increasing $\mathrm{NaCl}$ content, as used in our experiments. The $d_{P C}$ and $d_{D N A+P C}$ versus $\lambda_{D}$ are shown in Fig. 8 . The repeat distances depend almost linearly on the Debye screening length

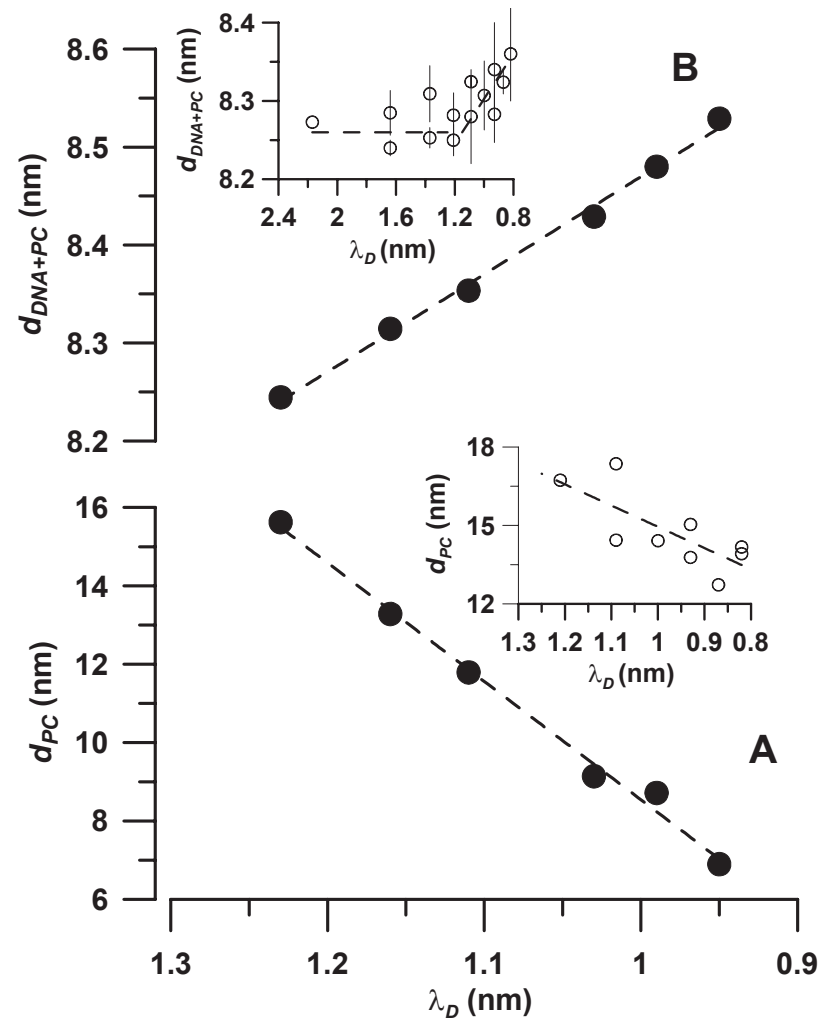

Figure 8. Repeat distances $d_{P C}(\mathrm{~A})$ and $d_{D N A+P C}(\mathrm{~B})$ as a function of Debye screening length $\lambda_{D}$.

(with correlation coefficients $\mathrm{R}^{2} \sim 0.993-0.995$ ). Neither the repeat distance nor the lipid bilayer thickness of neutral phospholipid have changed in 1-500 $\mathrm{mmol} / \mathrm{l} \mathrm{NaCl}$ (Pabst et al. 2007). Evidently, the electrostatic screening of $\mathrm{Zn}^{2+}$ charge due to ions accumulation and formation of a diffuse double layer are responsible for the observed changes in the repeat distances. The $d_{P C}$ as a function of $\lambda_{D}$ for DNA + DPPC mixtures in $20-45 \mathrm{mmol} / 1 \mathrm{ZnCl}_{2}$ (and $5 \mathrm{mmol} / \mathrm{l}$ $\mathrm{NaCl}$ ) shows a similar dependence (Fig. $8 \mathrm{~A}$, inset). At lower concentrations $(<20 \mathrm{mmol} / \mathrm{l}), \mathrm{Zn}^{2+}$ cations are involved in DNA - DPPC binding or in the bridging of DPPC molecules (Fig. 8B, inset). The minima in electrostatic free energy occur when the fixed negative charges on DNA surface are balanced by the same number of positive charges on the bilayer surface, i.e., at the isoelectric point. Because of the high mobility of metal cations, the evaluation of the isoelectric point in our system is not a trivial task. Our experiments do not allow us to determine the composition of the mixture at the isoelectric point; however, they indicate an excess of cations when DNA + DPPC are hydrated in $20 \mathrm{mmol} / \mathrm{ZnCl}_{2}$. We found the average repeat distance $d_{D N A+P C}=8.26 \pm 0.04 \mathrm{~nm}$ in the concentration range $5-20 \mathrm{mmol} / \mathrm{l}$ of $\mathrm{ZnCl}_{2}$. The steric lipid bilayer thickness of DPPC at $20^{\circ} \mathrm{C}$ is $d_{L}=5.26 \pm 0.03$ $\mathrm{nm}$, and may increase due to divalent cations binding (e.g. 
in the presence of calcium we found the maximal increase $\left.\Delta d_{L}=0.18 \pm 0.07 \mathrm{~nm}\right)$. Thus, for the interbilayer distance, we find $d_{h}=d_{D N A+P C}-d_{L}=2.82 \pm 0.14 \mathrm{~nm}$. The diameter of DNA strands is $2 \mathrm{~nm}$. The minimal interbilayer distance $2.6 \mathrm{~nm}$ is usually treated in theoretical works (Harries et al. 1998; May et al. 2000), representing the short-range repulsive forces arising from hydration, protrusion, and other excluded volume interactions (Israelachvili and Wennerstrom 1990; Israelachvili 1992). The obtained $d_{h}$, as well as the increase in $d_{D N A+P C}$ due to increasing ionic strength offer enough room for a layer of ions between DNA and the DPPC bilayer surfaces. These layers are responsible for the temperature instability of DNA $+\mathrm{DPPC}+\mathrm{Zn}^{2+}$ phase in the mixtures. It is worth to mention that DNA + neutral phospholipids + divalent cations aggregates show a high structural variety dependent on used DNA length fragments, phospholipids and cations. For example, the DNA + DPPC mixture in 20 $\mathrm{mmol} / 1 \mathrm{ZnCl}_{2}$ was stable up to $80^{\circ} \mathrm{C}$ with highly polymerized calf thymus DNA. Similarly, condensed lamellar phases of $\mathrm{DNA}+\mathrm{DPPC}+\mathrm{Ca}^{2+}$ at $20 \mathrm{mmol} / \mathrm{l} \mathrm{CaCl}_{2}$ with salmon sperm short fragmented DNA has kept its organization up to $80^{\circ} \mathrm{C}$. We have not observed any dissolution in aggregates with calf thymus DNA and DOPC in $1-80 \mathrm{mmol} / \mathrm{l} \mathrm{CaCl}_{2}$ or $\mathrm{MgCl}_{2}$ up to $90^{\circ} \mathrm{C}$, even when short fragmented calf thymus DNA was used (Uhríková et al. 2005a). Surface charge density and elastic properties of the phospholipid hydrophobic core are determining parameters for the polymorphic behaviour of DNA-cationic vesicles (May and Ben Shaul 2004). The binding affinity of divalent ions to the lipid bilayer depends on the used cation, the phase state of the phospholipid, and on the degree of unsaturation of the hydrocarbon chain (Altenbach and Seelig 1984), which all together offers a large variety of possible structural organization of the aggregates.

\section{Conclusion}

DSC, small angle neutron scattering and X-ray diffraction were used to examine the structural organization of DNA + $\mathrm{DPPC}+\mathrm{Zn}^{2+}$ mixtures as a function of zinc concentration and temperature. Experiments revealed the coexistence of two phases in the mixture: a $L_{P C}$ phase due to $\mathrm{Zn}^{2+}$ binding to the DPPC bilayer, and a condensed lamellar phase $L_{D N A+P C}$ with DNA strands packed between the DPPC bilayers. With increasing concentration of zinc, the temperature of the gel - liquid-crystal phase transition of DPPC increases in both phases, and the volume fraction of $L_{D N A+P C}$ phase decreases. SANS and SAXD indicate the following structural organization of the mixture: in the gel state, the repeat distance of $L_{D N A+P C}$ phase is constant, $d_{D N A+P C} \sim 8.3 \mathrm{~nm}$ up to $20 \mathrm{mmol} / \mathrm{l}$ of $\mathrm{ZnCl}_{2}$. Further increase in zinc concentration induces an increase in the $d_{D N A+P C}$. The periodicity of the $L_{P C}$ lamellar phase decreases substantially with increasing concentration of salt in the mixture. The screening of $\mathrm{Zn}^{2+}$ charges and the formation of a diffuse double layer due to increasing amount of ions are responsible for the observed changes. In the liquid-crystalline state, this diffuse double layer causes the dissolution of $L_{D N A+P C}$ phase into DPPC + $\mathrm{Zn}^{2+}$ unilamellar vesicles and DNA is neutralized by $\mathrm{Zn}^{2+}$ ions. The DNA + DPPC mixture in $20 \mathrm{mmol} / 1 \mathrm{ZnCl}_{2}$ did not show any regular organization at $60^{\circ} \mathrm{C}$. The temperature stability of the $L_{D N A+P C}$ phase increases with decreasing concentration of zinc.

Our experiments revealed that zinc at very low concentrations (of the order of millimoles) mediates the DNA-DPPC binding. These concentrations can be physiologically relevant, meaning that these experimental results will lead to subsequent studies. Further, the structure of the aggregates is interesting also as a model for contact sites between DNA and biomembranes, which is important in cellular processes (Kuvichkin 2002).

The reversible effect of the aggregate dissolution (condensed lamellar phase $\leftrightarrow$ unilamellar DPPC vesicles + DNA + ions), induced by the phase transition of the lipid was not studied in the literature yet. Our experiments may help to the understanding of the toxicity of heavy metals.

Acknowledgements. We wish to thank Prof. Pavol Balgavý for many years of fruitful collaboration, and D. U. thanks for the motivation in the study of DNA-cationic liposomes. This work was supported by the European Community under the FP6 programs: RII3-CT-2004-506008 and RII3-CT-2003-505925; by the JINR project 07-4-1069-09/2011, by the VEGA grant No. 1/0292/09 to D. U., and by FCT financing to CIQ(UP). D. U. thanks the Department of Chemistry, Faculty of Sciences, University of Porto, Portugal for their hospitality and Dr. Guangyue Bai for the help with calorimetric experiments.

\section{References}

Akashi K., Miyata H., Itoh H., Kinosita K. (1998): Formation of giant liposomes promoted by divalent cations: Critical role of electrostatic repulsion. Biophys. J. 74, 2973-2982; doi:10.1016/S0006-3495(98)78004-X

Altenbach Ch., Seelig J. (1984): Ca2+ binding to phosphatidylcholine bilayers as studied by deuterium magnetic resonance. Evidence for the formation of a Ca2+ complex with two phospholipid molecules. Biochemistry 23, 3913-3920; doi:10.1021/bi00312a019

Aruga S., Kataoka R., Mitaku S. (1985): Interaction between Ca2+ and dipalmitoylphosphatidylcholine membranes. I. Transition anomalies of ultrasonic properties. Biophys. Chem. 21, 265-275; doi:10.1016/0301-4622(85)80014-4

Balgavý P., Dubničková M., Uhríková D., Yaradaikin S., Kiselev M., Gordeliy V. (1998): Bilayer thickness in unilamellar extruded egg yolk phosphatidylcholine liposomes: a small-angle neutron scattering study. Acta Phys. Slovaca 48, 509-533 
Balgavý P., Dubničková M., Kučerka N., Kiselev M. A., Yaradaikin S. P., Uhríková D. (2001): Bilayer thickness and lipid interface area in unilamellar extruded 1,2-diacylphosphatidylcholine liposomes: a small-angle neutron scattering study. Biochim. Biophys. Acta 1512, 40-52; doi:10.1016/S0005-2736(01)00298-X

Binder H., Arnold K., Ulrich A. S., Zschornig O. (2000): The effect of $\mathrm{Zn} 2+$ on the secondary structure of a histidine-rich fusogenic peptide and its interaction with lipid membranes. Biochim. Biophys. Acta 1468, 345-358; doi:10.1016/ S0005-2736(00)00275-3

Binder H., Arnold K., Ulrich A. S., Zschornig O. (2001): Interaction of $\mathrm{Zn} 2+$ with phospholipid membranes. Biophys. Chem. 90, 57-74; doi:10.1016/S0301-4622(01)00130-2

Binder H., Zschornig O. (2002): The effect of metal cations on the phase behavior and hydration characteristics of phospholipid membranes. Chem. Phys. Lipids 115, 39-61; doi:10.1016/S0009-3084(02)00005-1

Bruinsma R., Mashl J. (1998): Long-range electrostatic interaction in DNA-cationic lipid complexes. Europhys. Lett. 41, 165-170; doi:10.1209/epl/i1998-00125-0

Budker V. G., Kazatchkov Y. A., Naumova L. P. (1978): Polynucleotides adsorb on mitochondrial and model lipid membranes in the presence of bivalent cations. FEBS Lett. 95, 143-146; doi:10.1016/0014-5793(78)80070-2

Cakmak I. (2000): Possible roles of zinc in protecting plant cells from damage by reactive oxygen species. New Phytol. 146, 185-205; doi:10.1046/j.1469-8137.2000.00630.x

Chapman D. (1962): The polymorphism of glycerides. Chem. Rev. 62, 433-453; doi:10.1021/cr60219a003

Christianson D. W. (1991): Sructural biology of zinc. Adv. Protein Chem. 42, 281-355; doi:10.1016/S00653233(08)60538-0

Eichhorn G. L., Shin Y. A. (1968): Interaction of metal ions with polynucleotides and related compounds. XII. The relative effect of various metal ions on DNA helicity. J. Am. Chem. Soc. 90, 7323-7328; doi:10.1021/ja01028a024

Feigin L. A., Svergun D. I. (1987): Structure Analysis by SmallAngle X-ray and Neutron Scattering. Plenum Publishing Corporation, New York, U.S.A.

Francescangeli O., Stanic V., Gobbi L., Bruni P., Iacussi M., Tosi G., Bernstorff S. (2003): Structure of self-assembled liposome-DNA-metal complexes. Phys. Rev. E 67, 011904; doi:10.1103/PhysRevE.67.011904

Francescangeli O., Pisani M., Stanic V., Bruni P., Weiss T. M. (2004): Evidence of an inverted hexagonal phase in self-assembled phospholipid-DNA-metal complexes. Europhys. Lett. 67, 669-675; doi:10.1209/epl/i2004-10091-y

Gershon H., Ghirlando R., Guttman S. B., Minsky A. (1993): Mode of formation and structural features of DNA cationic liposome complexes used for transfection. Biochemistry 32, 7143-7151; doi:10.1021/bi00079a011

Glatter O., Kratky O. (1983). Small Angle X-Ray Scattering. Academic Press, New York, U.S.A.

Gresh N., Šponer J. (1999): Complexes of pentahydrated Zn2+ with guanine, adenine, and the guanine-cytosine and adenine-thymine base pairs. Structures and energies characterized by polarizable molecular mechanics and $\mathrm{ab}$ initio calculations. J. Phys. Chem. B 103, 11415-11427; doi:10.1021/jp9921351

Harries D., May S., Gelbart W. M., Ben Shaul A. (1998): Structure, stability, and thermodynamics of lamellar DNA-lipid complexes. Biophys. J. 75, 159-173; doi:10.1016/S00063495(98)77503-4

Hauser H. (1993): Phospholipid vesicles. In: Phospholipid Handbook. (Ed. G. Cevc), pp. 603-637, Marcel Dekker, Inc., New York, U.S.A.

Huster D., Arnold K. (1998): Ca2+-mediated interaction between dextran sulfate and dimyristoyl-sn-glycero-3-phosphocholine surfaces studied by H-2 nuclear magnetic resonance. Biophys. J. 75, 909-916; doi:10.1016/S00063495(98)77579-4

Huster D., Paasche G., Dietrich U., Zschornig O., Gutberlet T., Gawrisch K., Arnold K. (1999): Investigation of phospholipid area compression induced by calcium-mediated dextran sulfate interaction. Biophys. J. 77, 879-887; doi:10.1016/S0006-3495(99)76939-0

Inoko Y., Yamaguchi T., Furuya K., Mitsui T. (1975): Effects of cations on dipalmitoyl phosphatidylcholine/cholesterol/water systems. Biochim. Biophys. Acta 413, 24-32; doi:10.1016/0005-2736(75)90055-3

Israelachvili J. N., Wennerstrom H. (1990): Hydration or steric forces between amphiphilic surfaces. Langmuir 6, 873-876; doi:10.1021/la00094a028

Israelachvili J. N. (1992): Intermolecular and Surface Forces. Academic Press, San Diego, CA, U.S.A.

Izumitani Y. (1994): Cation dipole interaction in the lamellar structure of DPPC bilayers. J. Colloid Interface Sci. 166, 143-159; doi:10.1006/jcis.1994.1281

Izumitani Y. (1996): A theory of the effects of the field-dependent affinity of calcium ions on the lamellar phase of dipalmitoyl lecithin. J. Colloid Interface Sci. 182, 6-16; doi:10.1006/jcis.1996.0431

Kejnovsky E., Kypr J. (1998): Millimolar concentrations of zinc and other metal cations cause sedimentation of DNA. Nucleic Acids Res. 26, 5295-5299; doi:10.1093/nar/26.23.5295

Khusainova R. S., Dawson K. A., Rochev Ia. A., Gorelov A. V., Ivanitskii G. R. (1999): Structural changes in DNA-Ca2+-dipalmitoylphosphatidylcholine complexes during changes in the molar ratio of nucleotide/lipid. Microcalorimetric study. Dokl. Akad. Nauk 367, 553-556 (in Russian)

Knoll W., Haas J., Sturhrmann H. B., Fuldner H. H., Vogel H., Sackmann E. (1981): Small-angle neutron scattering of aqueous dispersions of lipids and lipid mixtures. A contrast variation study. J. Appl. Crystallogr. 14, 191-202; doi:10.1107/S0021889881009102

Koltover I., Salditt T., Radler J. O., Safinya C. R. (1998): An inverted hexagonal phase of cationic liposome-DNA complexes related to DNA release and delivery. Science 281, 78-81; doi: $10.1126 /$ science. 281.5373 .78

Koltover I., Salditt T., Safinya C. R. (1999): Phase diagram, stability, and overcharging of lamellar cationic lipid-DNA self-assembled complexes. Biophys. J. 77, 915-924; doi:10.1016/ S0006-3495(99)76942-0

Kotalová M., Žiaková A., Balgavý P. (2008): Phase transitions in unilamellar DPPC liposomes containing primary 
aliphatic alcohols. Acta Facult. Pharm. Univ. Comenianae 55, 129-134

Kovalenko D. V., Shafei R. A., Zelenina I. A., Semenova M. L., Samuilova O. V., Zhdanov R. I. (1996): Metallonucleoliposome complexes as a vehicle for gene delivery to mouse skeletal muscles in vivo. Genetika 32, 1299-1301 (in Russian)

Koynova R., Caffrey M. (1998): Phases and phase transitions of the phosphatidylcholines. Biochim. Biophys. Acta 1376, 91-145

Kučerka N., Uhríková D., Teixeira J., Balgavý P. (2003): Lipid bilayer thickness in extruded liposomes prepared from 1,2-diacylphosphatidylcholines with monounsatured acyl chains: a small-angle neutron scattering study. Acta Facult. Pharm. Univ. Comenianae 50, 78-89

Kučerka N., Nagle J. F., Feller S. E., Balgavý P. (2004): Models to analyze small-angle neutron scttering from unilamellar vesicles. Phys. Rev. E 69, 0519031-0519039

Kuvichkin V. V. (2002): DNA-lipid interactions in vitro and in vivo. Bioelectrochemistry 58, 3-12; doi:10.1016/S15675394(02)00123-8

MacDonald R. C., MacDonald R. I., Menco B. P., Takeshita K., Subbarao N. K., Hu L. R. (2001): Small-volume extrusion apparatus for preparation of large, unilamellar vesicles. Biochim. Biophys. Acta 1061, 297-303

Marmur J., Doty P. (1962): Determination of the base composition of deoxyribonucleic acid (DNA) from its thermal denaturation temperature. J. Mol. Biol. 5, 109-118; doi:10.1016/S0022-2836(62)80066-7

May S., Ben-Shaul A. (2004): Modeling of cationic lipid-DNA complexes: non-viral vectors for gene therapy and drug delivery. Curr. Med. Chem. 11, 151-167; doi:10.2174/ 0929867043456142

May S., Harries D., Ben Shaul A. (2000): The phase behavior of cationic lipid-DNA complexes. Biophys. J. 78, 1681-1697; doi:10.1016/S0006-3495(00)76720-8

McManus J. J., Rädler J. O., Dawson K. A. (2003): Phase behaviour of DPPC in a DNA-calcium-zwitterionic lipid complex studied by SAXS. Langmuir 19, 9630-9637; doi:10.1021/ la034878q

Moore W. J. (1972): Physical Chemistry. (4th edition) Prentice-Hall, Inc., New Jersey, U.S.A.

Nagle J. F., Tristram-Nagle S. (2000): Structure of lipid bilayers. Biochim. Biophys. Acta 1469, 159-195

Nawroth T., Conrad H., Dose K. (1989): Neutron small angle scattering of liposomes in the presence of detergents. Physica B 156, 477-480; doi:10.1016/0921-4526(89)90708-4

Pabst G., Hodzic A., Štrancar J., Danner S., Rappolt M., Laggner P. (2007): Rigidification of neutral lipid bilayers in the presence of salts. Biophys. J. 93, 2688-2696; doi:10.1529/ biophysj.107.112615

Rädler J. O., Koltover I., Salditt T., Safinya C. R. (1997): Structure of DNA-cationic liposome complexes: DNA intercalation in multilamellar membranes in distinct interhelical packing regimes. Science 275, 810-814; doi:10.1126/ science.275.5301.810

Roveri N., Bigi A., Castellani P. P., Foresti E., Marchini M., Strocchi R. (1980): Study of rat tail tendon by x-ray diffraction and freeze-etching technics. Boll. Soc. Ital. Biol. Sper. 56, 953-959 (in Italian)

Sato Y., Kumazawa N., Yoshikawa K., Kurusu Y. (2005): Transformation of Escherichia coli mediated by neutral phospholipids. Biosci. Biotechnol. Biochem. 69, 235-237; doi:10.1271/bbb.69.235

Scherer P. G., Seelig J. (1989): Electric charge effects on phospholipid headgroups. Phosphatidylcholine in mixtures with cationic and anionic amphiphiles. Biochemistry 28, 7720-7728; doi:10.1021/bi00445a030

Šponer J., Burda J. V., Sabat M., Leszczynski J., Hobza P. (1998): Interaction between the guanine-cytosine Watson-Crick DNA base pair and hydrated group $\mathrm{IIa}(\mathrm{Mg} 2+, \mathrm{Ca} 2+$, $\mathrm{Sr} 2+, \mathrm{Ba} 2+)$ and group IIb (Zn2+, $\mathrm{Cd} 2+, \mathrm{Hg} 2+)$ metal cations. J. Phys. Chem. A 102, 5951-5957; doi:10.1021/ jp980769m

Tarahovsky Y. S., Khusainova A. V., Gorelov A. V., Nicolaeva T. I., Deev A. A., Dawson A. K., Ivanitsky G. R. (1996): DNA initiates polymorphic structural transitions in lecithin. FEBS Lett. 390, 133-136; doi:10.1016/00145793(96)00643-6

Tarahovsky Y. S., Deev A. A., Masulis I. S., Ivanitsky G. R. (1998): Structural organization and phase behavior of DNAcalcium-dipalmitoylphosphatidylcholine complex. Biochemistry Mosc. 63, 1126-1131

Uhríková D., Rapp G., Balgavý P. (2001): Condensation of DNA and phosphatidylcholine bilayers induced by $\mathrm{Mg}(\mathrm{II})$ ions - a synchrotron X-ray diffraction study. In: Challenges for Coordination Chemistry in the New Century. (Eds. M. Melník and A. Sirota), pp. 219-224, Slovak Technical University Press, Bratislava

Uhríková D., Rapp G., Balgavý P. (2002): Condensed lamellar phase in ternary DNA-DLPC-cationic gemini surfactant system: a small-angle synchrotron X-ray diffraction study. Bioelectrochemistry 58, 87-95; doi:10.1016/S15675394(02)00122-6

Uhríková D., Hanulová M., Funari S. S., Khusainova R. S., Šeršeň F., Balgavý P. (2005a): The structure of DNA-DOPC aggregates formed in presence of calcium and magnesium ions: a small angle synchrotron $\mathrm{X}$ ray diffraction study. Biochim. Biophys. Acta 1713, 15-28; doi:10.1016/ j.bbamem.2005.05.006

Uhríková D., Hanulová M., Lengyel A., Funari S. S., Balgavý P. (2005b): Microstructure of DNA-liposome aggregates in the presence of metal cations. Cell. Mol. Biol. Lett. 10, (Suppl.), 57-58

Uhríková D., Lengyel A., Hanulová M., Funari S. S., Balgavý P. (2007a): The structural diversity of DNA-neutral phospholipids-divalent metal cations aggregates: a small-angle synchrotron X-ray diffraction study. Eur. Biophys. J. 36, 363-375; doi:10.1007/s00249006-0086-2

Uhríková D., Teixeira J., Lengyel A., Almásy L., Balgavý P. (2007b): Formation of unilamellar dipalmitoylphosphatidylcholine vesicles promoted by $\mathrm{Ca} 2+$ ions: a small-angle neutron scattering study. Spectroscopy 21, 43-52

Uhríková D., Kučerka N., Teixeira J., Gordeliy V., Balgavý P. (2008): Structural changes in dipalmitoylphosphatidyl- 
choline bilayer promoted by Ca2+ ions: a small-angle neutron scattering study. Chem. Phys. Lipids 155, 80-89; doi:10.1016/j.chemphyslip.2008.07.010

Vojčíková L., Balgavý P. (1988): Interaction of DNA with dipalmitoylphosphatidylcholine model membranes: a microcalorimetric study. Studia Biophys. 125, 5-10

Vojčíková L., Švajdlenka E., Balgavý P. (1989): Spin label and microcalorimetric studies of the interaction of DNA with unilamellar phosphatidylcholine liposomes. Gen. Physiol. Biophys. 8, 399-406
Williams R. J. P. (1988): An introduction in biochemistry of zinc. In: Zinc in Human Biology. pp. 15-31, Springer-Verlag, London, UK

Yamada N. L., Seto H., Takeda T., Naga M., Kawabata Y., Inoue K. (2005): SAXS, SANS and NSE studies on "unbound state" in DPPC/water/CaCl2 system. J. Phys. Soc. Jpn. 74, 2853-2859; doi:10.1143/JPSJ.74.2853

Received: November 20, 2008

Final version accepted: March 4, 2009 